Article

\title{
Diel Variations in Cell Abundance and Trophic Transfer of Diarrheic Toxins during a Massive Dinophysis Bloom in Southern Brazil
}

\author{
Thiago Pereira Alves ${ }^{1,2, *}$ and Luiz Laureno Mafra Jr. ${ }^{1, *}$ \\ 1 Center for Marine Studies, Federal University of Paraná. Av. Beira-mar s/n, P.O. Box: 61, \\ Pontal do Paraná PR 83255-976, Brazil \\ 2 Federal Institute of Santa Catarina, Av. Ver. Abraão João Francisco, 3988, Ressacada, Itajaí SC 88307-303, Brazil \\ * Correspondence: thiago.alves@ifsc.edu.br (T.P.A.); mafrajr@gmail.com (L.L.M.J.); Tel.: +55-(47)-3390-1200 \\ (T.P.A.); +55-(41)-3511-8669 (L.L.M.J.); Fax: +55-(41)-3511-8648 (L.L.M.J.)
}

Received: 10 May 2018; Accepted: 4 June 2018; Published: 6 June 2018

\begin{abstract}
Dinophysis spp. are a major source of diarrheic toxins to marine food webs, especially during blooms. This study documented the occurrence, in late May 2016, of a massive toxic bloom of the Dinophysis acuminata complex along the southern coast of Brazil, associated with an episode of marked salinity stratification. The study tracked the daily vertical distribution of Dinophysis spp. cells and their ciliate prey, Mesodinium cf. rubrum, and quantified the amount of lipophilic toxins present in seston and accumulated by various marine organisms in the food web. The abundance of the D. acuminata complex reached $43 \times 10^{4}$ cells $\cdot \mathrm{L}^{-1}$ at $1.0 \mathrm{~m}$ depth at the peak of the bloom. Maximum cell densities of cryptophyceans and $M$. cf. rubrum $\left(>500 \times 10^{4}\right.$ and $18 \times 10^{4}$ cell. $\mathrm{L}^{-1}$, respectively) were recorded on the first day of sampling, one week before the peak in abundance of the D. acuminata complex. The diarrheic toxin okadaic acid (OA) was the only toxin detected during the bloom, attaining unprecedented, high concentrations of up to $829 \mu \mathrm{g} \cdot \mathrm{L}^{-1}$ in seston, and $143 \pm 93 \mathrm{pg} \cdot \mathrm{cell}^{-1}$ in individually picked cells of the D. acuminata complex. Suspension-feeders such as the mussel, Perna perna, and barnacle, Megabalanus tintinnabulum, accumulated maximum OA levels (up to 578.4 and $21.9 \mu \mathrm{g}$ total $\mathrm{OA} \cdot \mathrm{Kg}^{-1}$, respectively) during early bloom stages, whereas predators and detritivores such as Caprellidae amphipods $\left(154.6 \mu \mathrm{g} \cdot \mathrm{Kg}^{-1}\right)$, Stramonita haemastoma gastropods $\left(111.6 \mu \mathrm{g} \cdot \mathrm{Kg}^{-1}\right)$, Pilumnus spinosissimus crabs $\left(33.4 \mu \mathrm{g} \cdot \mathrm{Kg}^{-1}\right)$ and a commercially important species of shrimp, Xiphopenaeus kroyeri $\left(7.2 \mu \mathrm{g} \cdot \mathrm{Kg}^{-1}\right)$, only incorporated OA from mid- to late bloom stages. Conjugated forms of OA were dominant $(>70 \%)$ in most organisms, except in blenny fish, Hypleurochilus fissicornis, and polychaetes, Pseudonereis palpata (up to 59.3 and $164.6 \mu \mathrm{g}$ total $\mathrm{OA} \cdot \mathrm{Kg}^{-1}$, respectively), which contained mostly free-OA throughout the bloom. Although algal toxins are only regulated in bivalves during toxic blooms in most countries, including Brazil, this study indicates that human seafood consumers might be exposed to moderate toxin levels from a variety of other vectors during intense toxic outbreaks.
\end{abstract}

Keywords: harmful algal bloom; Diarrheic Shellfish Poisoning; okadaic acid; toxin accumulation; toxin vectors; trophic transfer; Brazil

Key Contribution: A massive toxic bloom of the Dinophysis acuminata complex associated with salinity stratification; Daily vertical distribution of Dinophysis spp. and Mesodinium cf. rubrum cells, and toxin in seston; Unprecedentedly high toxin cell quota in D. acuminata complex; Transfer of lipophilic toxins in the marine food web. 


\section{Introduction}

The frequency, duration and severity of Dinophysis blooms have increased worldwide over the past two decades [1], leading to numerous episodes of massive shellfish contamination by lipophilic toxins in Europe [2,3], Africa [4,5], Asia [6], North America [7], and South America [8-10]. Although scientific evidence indicates that the increase in harmful algal blooms may be correlated with mesoand large-scale physico-chemical processes, i.e., artificial eutrophication [11-14], and global climate change [15,16], possible causes for an apparent increase in Dinophysis blooms are less comprehended.

Neritic and oceanic Dinophysis spp. are frequently observed in offshore waters along the southern coast of Brazil [17]. In 2007, the first large-scale bloom of Dinophysis acuminata complex ever reported in this region caused intoxication of at least 170 human consumers of contaminated shellfish (mainly Perna perna mussels $[18,19]$ ) and led managers and regulators to issue a first-time ban for bivalve mollusk harvesting and commercialization. Recurrent small to medium-scale Dinophysis blooms in Brazil have been reported along the coasts of Paraná and Santa Catarina states since then [20,21]. In many cases, episodes of bivalve contamination have been reported based on Diarrheic Shellfish Poisoning (DSP) mouse bioassays [18,22]. Additionally, diarrheic toxins such as okadaic acid (OA) and their congeners dinophysistoxins (DTXs) have been detected by chemical analytical methods in plankton and marine fauna [20,22]. The current Brazilian national monitoring program for harmful algae and phycotoxins uses bivalves (especially brown mussels, Perna perna) as sentinel organisms for the presence of toxins in shellfish farming areas, and harvesting bans are issue anytime the regulatory toxin levels are surpassed, i.e., $160 \mu \mathrm{g} \cdot \mathrm{Kg}^{-1}$ in the case of diarrheic toxins [23].

Dinophysis spp. are a recurrent threat to shellfish aquaculture areas worldwide (reviewed by Reguera et al., [24]), where bloom initiation depends not only on favorable abiotic conditions, but also on the availability of ciliate prey [25]. Mixotrophy via the sequestration and retention of plastids from the ciliate Mesodinium cf. rubrum is now considered a key process enabling the development of Dinophysis populations both in the laboratory and in the field (e.g., [26,27]). Recent studies have focused on describing the feeding mechanism of Dinophysis spp., and elucidating the possible ecological roles of diarrheic toxins and other bioactives produced by the dinoflagellate [27-29]. A number of nutritional and trophic aspects related to toxic Dinophysis spp. blooms, such as small-scale interactions with $M$. cf. rubrum and possibly with other prey items in the field, however, remain unclear.

During Dinophysis blooms, lipophilic toxins can be transferred via several trophic pathways [30]. Toxins can be accumulated not only by bivalves, but also by polychaetes and ascidians [31], fish [32,33], octopuses [20] and crabs [34,35]. Dinophysis toxins may also be related to the death of monk seals off the coast of the western Sahara [36], although the implications of toxin incorporation for marine organisms remain poorly known. An understanding of small-scale trophic relationships underlying the initiation and development of Dinophysis blooms, as well as the fate of diarrheic toxins in marine food webs, are essential for the evaluation of their associated risks. The main objectives of this study are to (a) determine the diel vertical distribution of Dinophysis spp. and their prey in a shallow inlet, and (b) quantify the levels of lipophilic toxins present in seston and in marine organisms representative of different trophic levels, during a massive bloom of the Dinophysis acuminata complex in southern Brazil.

\section{Results}

\subsection{Plankton and Toxins in the Water Column}

Depth-averaged water temperature and salinity decreased gradually during the first half of the bloom period, from 26 May to 3 June, when the minimum salinities were recorded (mean \pm standard deviation $(\mathrm{SD})=24.2 \pm 0.55 ; n=6$ ). The water temperature continued to decrease thereafter, attaining a minimum of $16.8 \pm 0.1^{\circ} \mathrm{C}$ on the last sampling day, 16 June (Figure 1A,B). Secchi depth (Figure 1C,D) ranged from 1.8 to $2.8 \mathrm{~m}$ during the first half of the bloom and then gradually increased, attaining up to $3.6 \mathrm{~m}$ by the end of bloom. Chlorophyll- $a$ concentrations were relatively low $\left(0.47 \pm 0.17 \mathrm{SD} \mathrm{mg} \cdot \mathrm{m}^{-3}\right)$ throughout the 
study, and reached a maximum of $1.1 \mathrm{mg} \cdot \mathrm{m}^{-3}$ on 3 June, coinciding with the maximum peak of Dinophysis abundance. Decreasing concentrations of mean DIN $( \pm \mathrm{SD})$, especially those of nitrate $(2.3 \pm 0.9 \mu \mathrm{M})$ and ammonium $(2.5 \pm 0.7 \mu \mathrm{M})$ (Figure 1E), were associated with a concurrent decrease in salinity and temperature, and an increase in the abundance of $M$. cf. rubrum. Silicate and phosphate exhibited a marked increase during later stages of the bloom and attained the highest concentration range (39.6-88.7 $\mu \mathrm{M}$ and 1.3-6.3 $\mu \mathrm{M}$, respectively) by the end of the study period (Figure $1 \mathrm{~F}$ ).

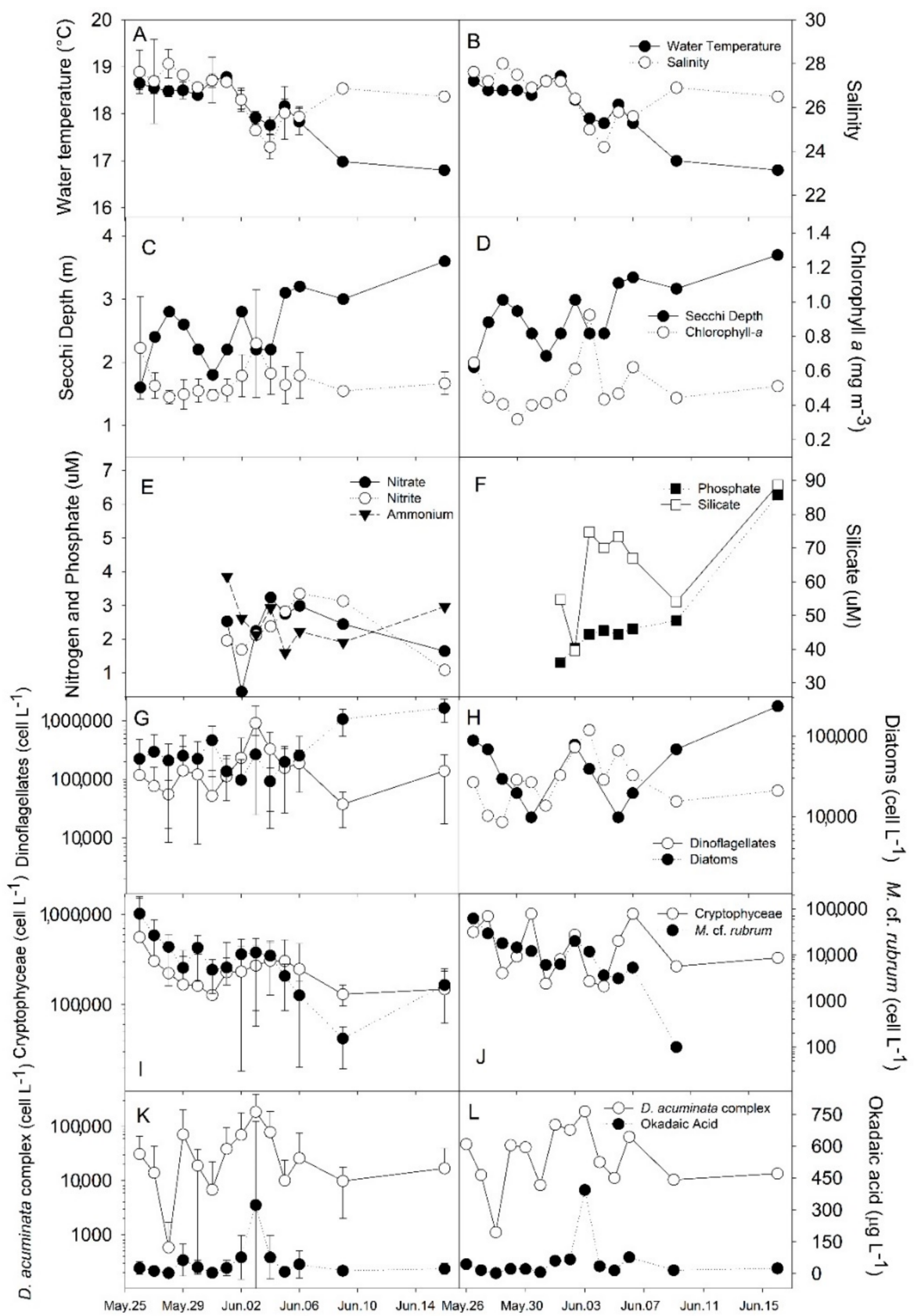

Figure 1. (A,C,G,I,K) Average values ( \pm standard deviation; $n=6)$ of depth-discrete measurements, and $(\mathbf{B}, \mathbf{D}, \mathbf{E}, \mathbf{F}, \mathbf{H}, \mathbf{J}, \mathbf{L})$ single depth-integrated measurements (taken with a hose extending from the surface to the bottom) for: $(\mathbf{A}, \mathbf{B})$ water temperature $\left({ }^{\circ} \mathrm{C}\right)$ and salinity ; (C,D) Secchi depth $(\mathrm{m})$ and chlorophyll- $a$ concentration $\left(\mathrm{mg} \cdot \mathrm{m}^{-3}\right)$; $(\mathbf{E}, \mathbf{F})$ concentration of dissolved inorganic nutrients $(\mu \mathrm{M}) ;(\mathbf{G}, \mathbf{H})$ numerical abundance (on log-scale) of dinoflagellates and diatoms (cells $\left.\cdot \mathrm{L}^{-1}\right) ;(\mathbf{I}, \mathbf{J})$ abundance of cryptophyceans and Mesodinium cf. rubrum (cells $\left.\cdot \mathrm{L}^{-1}\right) ;(\mathbf{K}, \mathbf{L})$ abundance of the Dinophysis acuminata spp. complex (cells $\cdot \mathrm{L}^{-1}$ ) and concentration of free okadaic acid $(\mathrm{OA})$ in suspended particulate matter $\left(\mu \mathrm{g} \cdot \mathrm{L}^{-1}\right)$. 
Diatom abundance remained at low to moderate levels $\left(<9 \times 10^{4}\right.$ cells $\left.\cdot \mathrm{L}^{-1}\right)$ during the first half of the bloom, rising up to $19 \pm 6.2 \times 10^{4}$ cells $\cdot \mathrm{L}^{-1}$ by the end of the sampling period, when they finally dominated the micro-phytoplankton assemblage (Figure 1H). Dinoflagellates were detected at cell densities comparable to those of diatoms during the first half of the study, attaining a maximum of $90 \pm 31.9 \times 10^{4}$ cells. $\mathrm{L}^{-1}$ and becoming dominant over diatoms on 3 June (Figure $1 \mathrm{H}$ ). Dinophysis species found during this bloom included the taxonomic complex composed by D. acuminata and D. ovum (referred to as D. acuminata complex hereafter), and D. caudata. This last species was frequently observed in plankton net samples during the first half of the bloom, although no cells were detected in most cell counts (LOD: 50 cells. $\mathrm{L}^{-1}$ ), except on 28 and 30 May (100 cells. $\mathrm{L}^{-1}$; not shown). The Dinophysis acuminata complex comprised the most abundant dinoflagellate cells and the main component of the total micro-phytoplankton assemblage throughout the study. Their depth-averaged cell density increased from $7.1 \pm 13.4 \times 10^{4}$ cells $\cdot \mathrm{L}^{-1}$ on the first sampling day to $18.7 \pm 20.1 \times 10^{4}$ cells $\cdot \mathrm{L}^{-1}$ (max. $43 \times 10^{4}$ cells $\cdot \mathrm{L}^{-1}$ at $1.0 \mathrm{~m}$ depth) on 3 June (Figure $1 \mathrm{~K}$ ), coinciding with a gradual decrease in the abundance of the ciliate $M$. cf. rubrum (Figure 1I). At the beginning of the bloom, average cell densities of cryptophyceans decreased at a rate comparable to that of $M$. cf. rubrum, and then increased slightly by the mid-bloom period, when $M$. cf. rubrum abundance reached minimum values (Figure 1I).

Water temperature (Kruskal-Wallis test statistic $\mathrm{H}=69.4 ; p=0.01$ ), Secchi depth $(\mathrm{H}=79.0 ; p=0.01$ ), salinity $(\mathrm{H}=55.5 ; p=0.01)$ and abundance of diatoms $(\mathrm{H}=34.3 ; p=0.01)$ all varied significantly during the study period. When depth layers were compared over time, however, there was no detectable difference in water temperature $(\mathrm{H}=0.24 ; p=0.99)$ or diatom abundance values $(\mathrm{H}=6.6$; $p=0.25)$ over time at any specific depth. The depth layer marking salinity stratification $(\mathrm{H}=14.8$; $p=0.01$ ) ranged from 2 to $3 \mathrm{~m}$ over the course of the bloom. Although peaks in the abundance of targeted taxa were clearly identified in time and space/depth, there were no statistically significant differences in the cell density of dinoflagellates, cryptophyceans, $M$. cf. rubrum and the D. acuminata complex, or in the concentrations of chl- $a$ and OA in SPM over time. Chlorophyll- $a$ concentrations $(\mathrm{H}=45.0 ; p<0.01)$, and the abundance of dinoflagellates $(\mathrm{H}=51.7 ; p<0.01)$, cryptophyceans $(\mathrm{H}=56.4 ; p<0.01)$, M. cf. rubrum $(\mathrm{H}=31.6 ; p<0.01)$, and the D. acuminata complex $(\mathrm{H}=53.4 ; p<0.01)$ all differed significantly between $0-2 \mathrm{~m}$ and 3-5 $\mathrm{m}$ depth, with higher values found in the upper water layer. In general, depth-integrated samples (those taken with a hose extending from surface to bottom), yielded very similar values to those calculated as the average of depth-discrete measurements, except for the abundance of cryptophyceans $(\mathrm{H}=20.3 ; p<0.01)$, which was typically greater when estimated from integrated samples (Figure 1I,J).

The onset of the bloom (on 26 May) was marked by pronounced surface stratification in salinity and water temperatures around $18^{\circ} \mathrm{C}$ (Figure 2). After 2-3 days, salinity stratification was disrupted and the temperature increased by $1.0^{\circ} \mathrm{C}$, decreasing thereafter to a minimum of $17^{\circ} \mathrm{C}$ by the 10 th day (4 June), when the water column again became salinity-stratified (Figure 2). Water temperature ranged from 17 to $19.5{ }^{\circ} \mathrm{C}$ and salinity from 23 to 29 over time. The relatively high Secchi-depth values $(>2.0 \mathrm{~m})$ obtained during the study indicate that the euphotic zone always reached the bottom in the sampling area. 


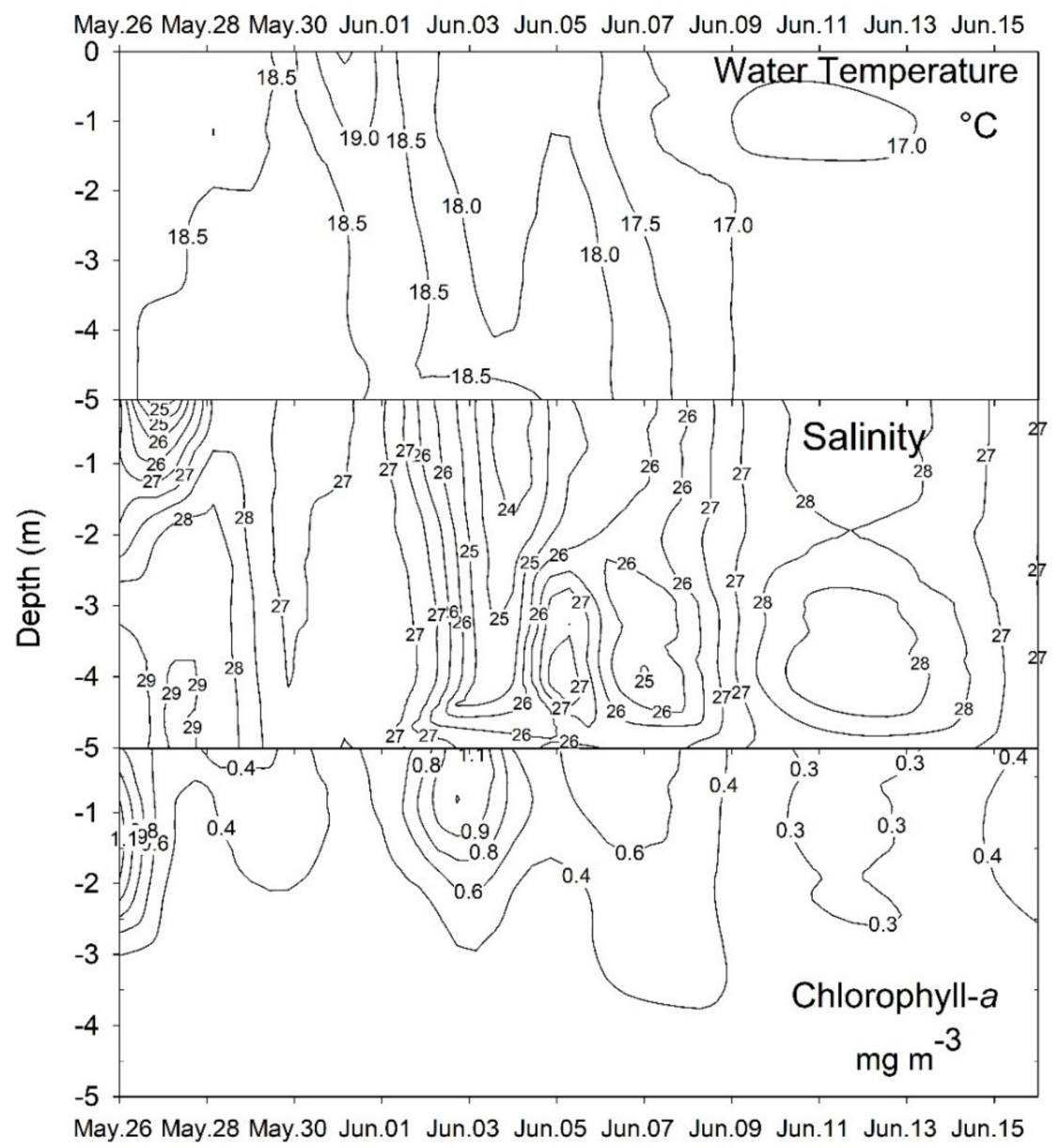

Figure 2. Interpolated depth-discrete measurements of water temperature $\left({ }^{\circ} \mathrm{C}\right)$, salinity, and chlorophyll a concentration $\left(\mathrm{mg} \cdot \mathrm{m}^{-3}\right)$, over the course of the study.

Chlorophyll- $a$ concentrations were higher during periods of salinity stratification. Values $\geq 1.0 \mathrm{mg} \cdot \mathrm{m}^{-3}$ were attained on two occasions, on the 1st and the 9th day of sampling (26 May and 3 June), with a third peak $\left(>0.6 \mathrm{mg} \cdot \mathrm{m}^{-3}\right)$ a few days later (Figures 1D and 2). In all cases, higher concentrations were restricted $(\mathrm{H}=0.45 ; p<0.01)$ to the surface layer $(0-2 \mathrm{~m})$. Likewise, the abundance of the main taxa investigated-cryptophyceans, $M$. cf. rubrum and Dinophysis-also varied vertically, exhibiting higher values in the upper water layer. Maximum values for cryptophyceans and M. cf. rubrum $\left(>500 \times 10^{4}\right.$ and $18 \times 10^{4}$ cell. $\mathrm{L}^{-1}$, respectively) were measured on the first day of sampling. During subsequent days, their abundance decreased concomitantly with a rapid increase of the $D$. acuminata complex cell density, reaching $>20 \times 10^{4}$ cells $\cdot \mathrm{L}^{-1}$ on 29 May and $>40 \times 10^{4}$ cells $\cdot \mathrm{L}^{-1}$ on 3 June, one week following the initial peak in M. cf. rubrum abundance (Figure 3), and coincident with the second episode of salinity stratification. Higher cell abundances of the D. acuminata complex were restricted to the surface layer $(>2 \mathrm{~m})$, where concentrations of free-OA $>600 \mu \mathrm{g} \cdot \mathrm{L}^{-1}$ were simultaneously detected in the $\operatorname{SPM}(>0.45-\mu \mathrm{m}$ particles $)$. During the period of maximum dinoflagellate cell density, the OA cellular quota, as measured from individually-picked cells of the $D$. acuminata complex ranged from $48 \pm 31 \mathrm{SD}$ pg.cells ${ }^{-1}(n=137-208$ cells per sample) on 2 June to $143 \pm 93 \mathrm{pg} \cdot \mathrm{cell}^{-1}(n=141-220)$ on 3 June. 


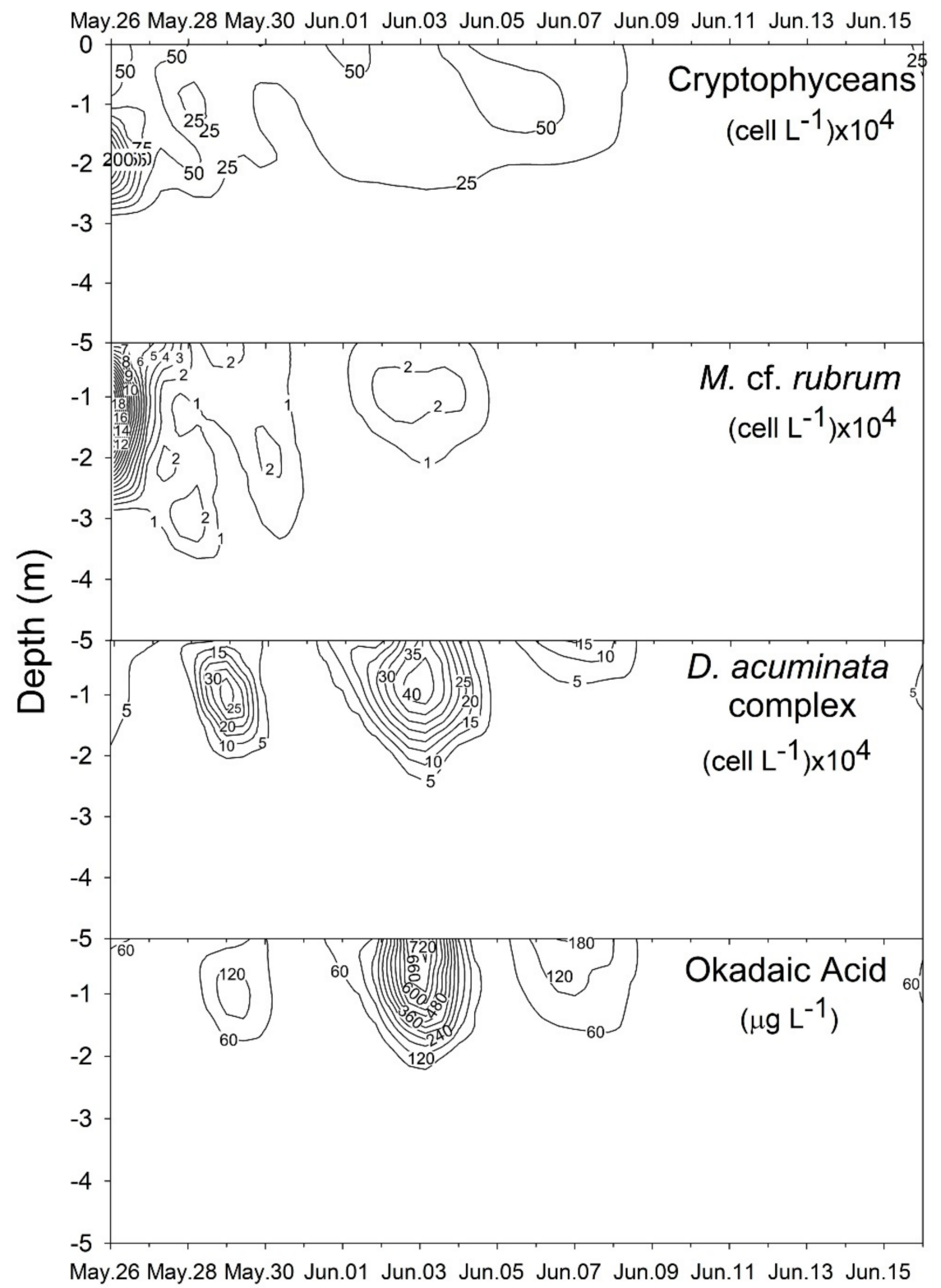

Figure 3. Depth profile of the cell abundance of the main plankton taxonomic groups (cell. $\mathrm{L}^{-1} \times 10^{4}$ ) (top three panels) and the concentration of okadaic acid $\left(\mu \mathrm{g} \cdot \mathrm{L}^{-1}\right)$ in suspended particulate matter (bottom panel) during the study period.

\subsection{Diarrheic Toxins in Marine Fauna}

All selected marine faunal components accumulated detectable OA levels during the study. Toxin levels were directly associated with the presence of $D$. acuminata complex cells in the water column; maximum values depended on the species and trophic position of the organisms. Suspension-feeding mussels and barnacles were the first to accumulate detectable levels of OA in their tissues and the only ones to contain detectable toxin levels during the entire sampling period. Mussels accumulated the highest OA concentrations among all organisms analyzed, with toxin levels gradually increasing following an increase in cell density of the D. acuminata complex. They attained a maximum of $549.6 \mu \mathrm{g}$ total OA$\cdot \mathrm{Kg}^{-1}$ (wet tissue weight) on 4 June (Figure 4), only one day after the peak abundance of the dinoflagellate. Polychaete worms $\left(\max .=164.5 \mu \mathrm{g}\right.$ total OA $\cdot \mathrm{Kg}^{-1}$ ), amphipods $\left(\max .=153.7 \mu \mathrm{g}\right.$ total $\left.\mathrm{OA} \cdot \mathrm{Kg}^{-1}\right)$ and gastropods $\left(\max .=111.6 \mu \mathrm{g}\right.$ total $\left.\mathrm{OA} \cdot \mathrm{Kg}^{-1}\right)$ also retained relatively high toxin amounts, but not before the mid-bloom stage. Amphipods and to 
some extent fish $\left(\max .=56.2 \mu \mathrm{g}\right.$ total $\left.\mathrm{OA} \cdot \mathrm{Kg}^{-1}\right)$, remained contaminated for shorter periods, i.e., only when OA concentrations in the SPM were maximal (early to mid-bloom period). In contrast, gastropods, polychaetes, crabs $\left(\max .=33.3 \mu \mathrm{g}\right.$ total $\left.\mathrm{OA} \cdot \mathrm{Kg}^{-1}\right)$ and shrimp $(\max .=7.2 \mu \mathrm{g}$ total $\mathrm{OA} \cdot \mathrm{Kg}^{-1}$ ) accumulated detectable toxin levels from the mid- to late bloom stage, after OA peaked in suspension (Figure 4).

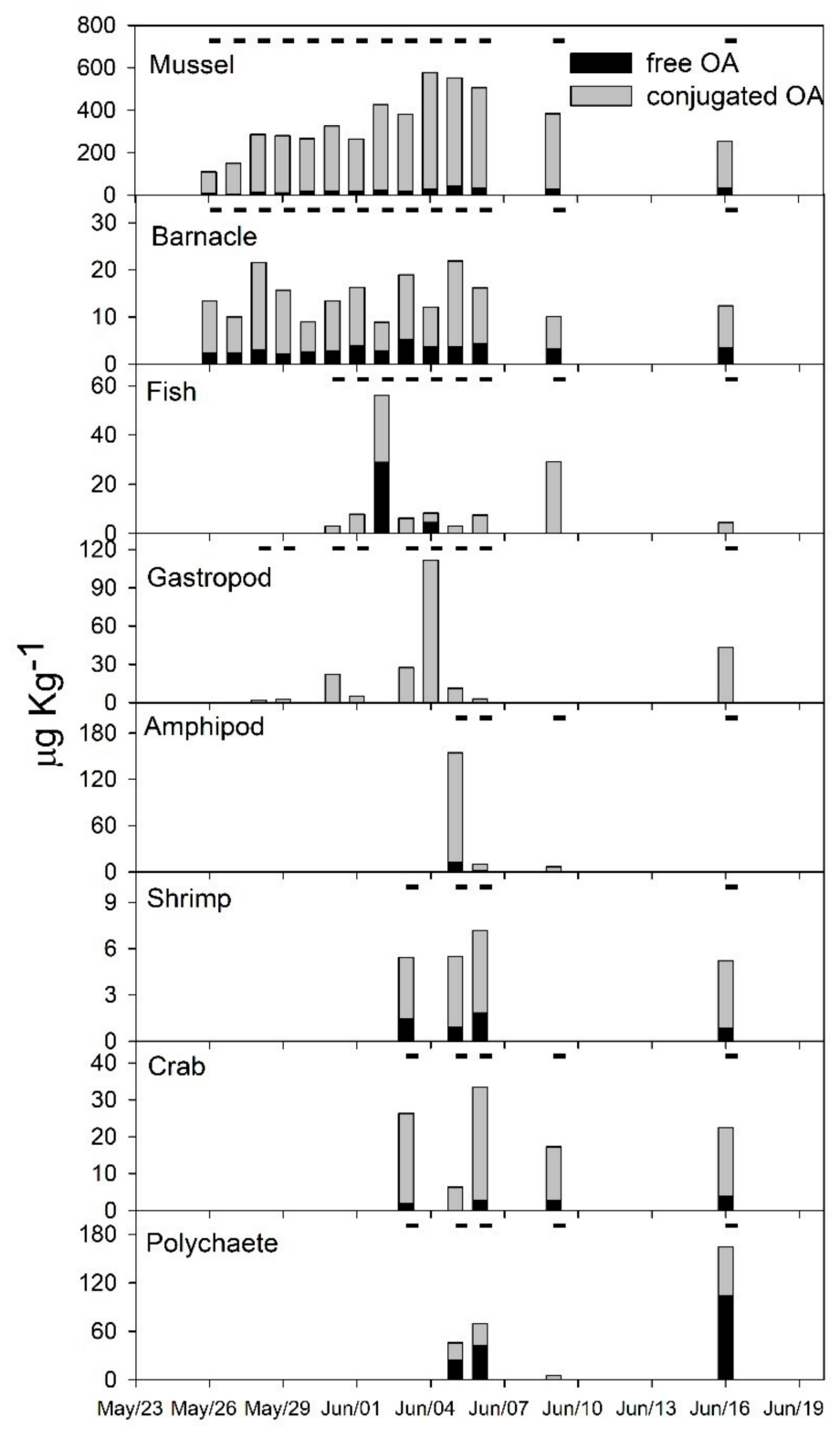

Figure 4. Concentration of okadaic acid $\left(\mathrm{OA}, \mu \mathrm{g} \cdot \mathrm{kg}^{-1}\right)$, in its free (black bars) and conjugated (gray bars) forms, accumulated in different marine organisms during the bloom of the Dinophysis acuminata spp. complex. Dashes above the composite bars denote the sampling dates when each marine organism was available.

Fish and polychaetes accumulated the greatest proportions of OA in its free form. The proportion of free-OA was slightly higher in fish ( $54 \pm 7 \%$ ) at the peak of the bloom, but still did not match that of polychaetes $(64 \pm 5 \%)$. The latter seemed to possess the least efficient detoxification mechanism, given the high proportions of free-OA and the constantly increasing total OA levels measured (Figure 4). Conversely, the conjugated forms of OA were dominant in all other organisms, including barnacles 
(76 $\pm 7 \%$ SD), shrimp (79 $\pm 5 \%)$, amphipods ( $87 \pm 5 \%)$, crabs $(90 \pm 7 \%)$, mussels $(94 \pm 2 \%)$ and gastropods, which never accumulated detectable levels of free-OA (i.e., exhibited $100 \%$ of OA as conjugated forms).

\subsection{Correlations}

As assessed by principal component analysis, salinity was strongly and inversely correlated with both the abundance of the D. acuminata complex and the concentration of OA in suspension (Figure 5). This grouping was also inversely, but less obviously associated with ammonium concentration and the abundance of cryptophyceans, and even less obviously with Secchi depth, phosphate concentration and the abundance of diatoms (Figure 5). These last three variables, as well as the concentration of silicate, were inversely correlated to $M$. cf. rubrum abundance, which, in turn, was strongly and directly associated with the abundance of cryptophyceans and the concentrations of nitrite and nitrate.

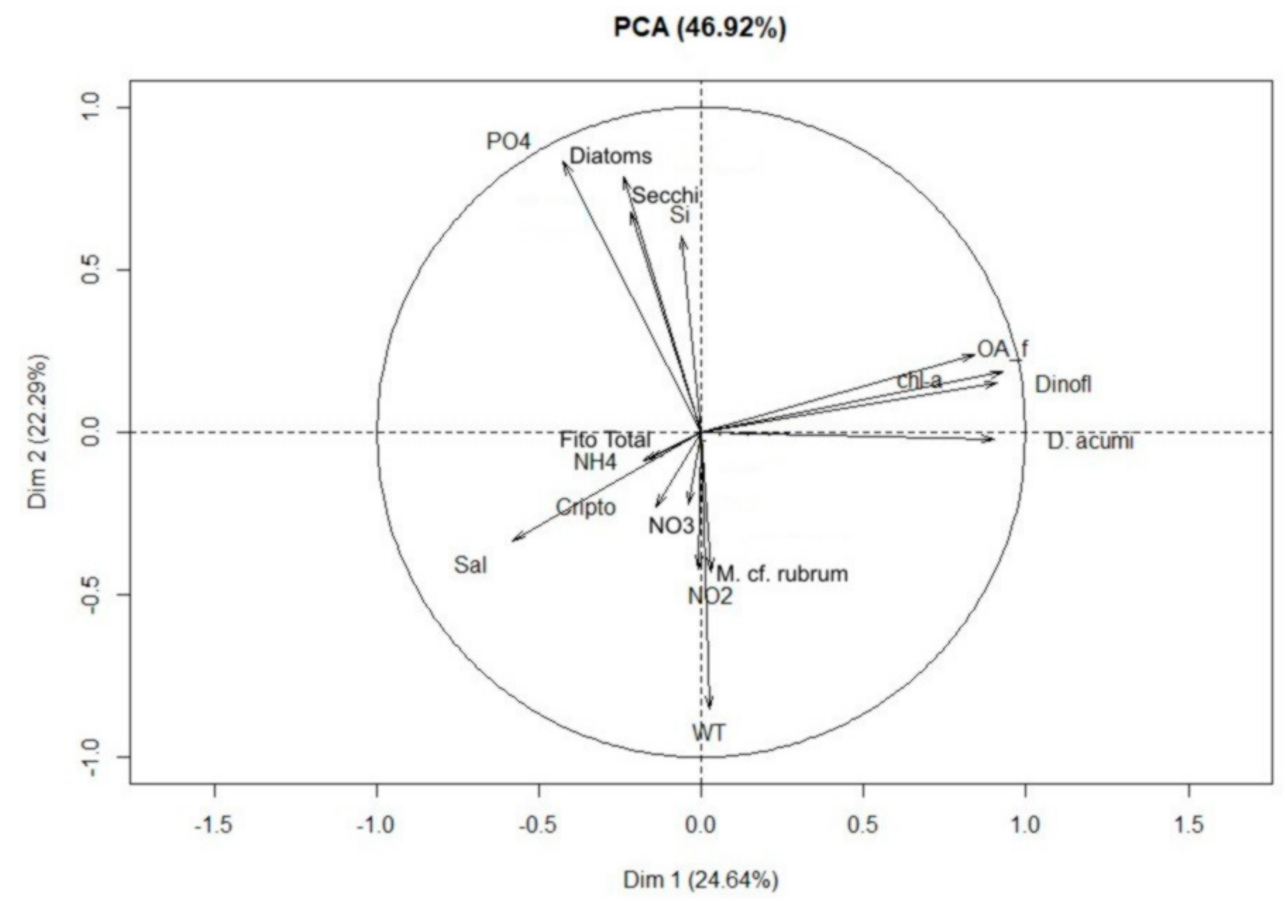

Figure 5. Principal Component Analysis (PCA) of discrete-depth measurements of the following variables: water temperature (WT), Salinity (Sal), Transparency (Secchi depth), Chlorophyll- $a$ (chl- $a$ ), Diatoms (Diatoms), Dinoflagellates (Dinofl), Cryptophyceans (Cripto), total micro-phytoplankton (Fito Total), Mesodinium cf. rubrum (M. cf. rubrum), D. acuminata complex (D. acumi), free okadaic acid (AO_f), Phosphate (PO4), Nitrate (NO3), Nitrite (NO2), Ammonium (NH4), and Silicate (Si) concentrations.

\section{Discussion}

\subsection{Bloom Development and Trophic Relationships}

In late May 2016, an episode of marked salinity stratification was associated with the onset of what can be considered the most intense bloom of the Dinophysis acuminata complex ever recorded along the Brazilian coast. The bloom only lasted for a few weeks along the coast of Santa Catarina State. It was then transported northward to Paraná State, where it reached even higher cell densities, causing massive contamination of marine fauna and intoxication of human seafood consumers [37]. Although results of the present study indicated that bivalves were also contaminated with unsafe OA levels in Santa Catarina, actions taken in the context of the local HAB monitoring and management program prevented cases of intoxication in this region. More importantly, however, the present study also documents the accumulation of diarrheic toxins in several other marine organisms associated with 
farmed mussels, some of them for the first time, indicating that multiple toxin vectors and transfer routes should be considered during massive Dinophysis blooms.

Blooms of Dinophysis spp. are usually associated with marked thermohaline stratification of the water column [10,38-40]. The ciliate prey of Dinophysis spp., frequently reported as Mesodinium rubrum, usually benefits from vertical water stratification as well [41,42], although blooms of the ciliate may also occur along horizontal thermohaline gradients in shallow estuaries [43].

About one week preceding the maximum Dinophysis cell density recorded in Armação do Itapocoroy inlet during this study, high abundances of $M$. cf. rubrum and their cryptophycean prey $\left(10^{5}\right.$ to $10^{6}$ cells $\cdot \mathrm{L}^{-1}$, respectively) were observed in the upper water layer associated with lower salinities and strong stratification at $2 \mathrm{~m}$ depth. On the following 4-5 days, the abundance of cryptophyceans decreased rapidly, followed by a more gradual decrease in $M$. cf. rubrum cell density, as the abundance of cells belonging to the $D$. acuminata complex began to increase in the same surface layer. One week later, a second cryptophycean-ciliate-Dinophysis succession cycle occurred once water became stratified again. Although daily variations in the abundance of these three taxa may be partially linked to local advection, what was not the subject of this study; the succession pattern reported herein confirms that the trophic relationships documented in prior laboratory observations $[27,28,44-46]$ may also occur on a similar temporal scale under natural field conditions and sustain massive blooms of the toxic dinoflagellate. On other occasions (i.e., under lower availability of $M$. cf. rubrum cells), alternative prey items may provide Dinophysis spp. with an additional source of nutrients, as suggested for D. caudata preying upon the benthic ciliate Mesodinium coatsi [47].

The development of Dinophysis blooms in other geographical areas may also be linked to the intrusion of less saline water masses and/or to disturbances in physico-chemical water column structure, although the underlying processes might be different and sometimes occur on a wider spatio-temporal scale. Blooms may thus be either associated to upwelling, as verified in Sweden [48], Galicia (Spain) and Portugal [25], or to river plumes, as found in Tunisia [40] and Scotland [3]. They may also be associated with seasonal changes in wind patterns and the precipitation regime such as those recorded in Ireland [49], Greece [50] and Argentina [9,51]. On the eastern coast of South America, the water mass associated with the La Plata River plume promotes important large-scale changes in the physico-chemical characteristics of the water column along the coasts of NE Argentina, Uruguay and southern Brazil during fall and winter [52,53], when massive Dinophysis blooms are usually observed in this region $[54,55]$. This suggests that the La Plata water plume (PWP) may be one of the main factors controlling the development of large-scale Dinophysis blooms in southwestern Atlantic coastal waters.

Chlorophyll- $a$ concentrations did not vary substantially over time in the present study, and did not attain values exceeding the historical average for the region [56,57]. This could be explained by the uncommon prevailing phytoplankton succession, whereby one dominant taxon preys upon and acquires the plastids (and the pigments) from its precursor, rather than synthesizing its own pigment quota during a gradual competitive exclusion process. Whereas phosphate concentrations remained relatively high and even increased during the final bloom stage, those of dissolved nitrogen compounds, notably ammonium and nitrate, decreased over the course of the bloom, especially during the period of maximum cell abundance of the D. acuminata complex.

Both water sampling strategies used in this study (single integrated samples and multiple depth-discrete sampling) allowed adequate tracking of bloom development, yielding similar abundance values for both the toxic dinoflagellate and its prey, M. cf. rubrum. Therefore, as demonstrated in other areas such as Spain [58], depth-integrated sampling, undertaken with a hose extending from the surface to the bottom, provided a rapid and reliable early-warning tool in HAB monitoring and risk assessment in shallow waters affected by Dinophysis blooms along the southern coast of Brazil. However, special attention is required when applying the technique to ecological studies, as the abundance of cryptophyceans and perhaps other small-celled algal groups can be underestimated. Likewise, vertical migration and cell aggregation processes can be missed as a result of the "diluting" effect introduced by this sampling strategy. More importantly, adoption of Dinophysis cell abundance as early warning for DSP should be 
used conservatively, i.e., the threshold value should be kept cautiously low when integrated samples are used in HAB monitoring programs. One of the main ecological features of Dinophysis cells is their ability to aggregate in thin water layers, as reported in this and other studies [59], such that toxin food web transfer may be heterogeneous throughout the water column.

\subsection{Fate of Diarrheic Toxins during the Bloom}

Cells of the D. acuminata complex contained exclusively OA during the bloom described in this study, contrasting with a more complex toxin profile reported during previous blooms in Argentina $[10,60]$ and Chile [61], where D. acuminata and D. tripos, the species involved in the blooms, produced pectenotoxin-2 (PTX-2) and DTX-1 in addition to OA. It is noteworthy that DTX-1 has been reported in different southern Brazilian estuaries when lower Dinophysis spp. cell abundances $\left(<2 \times 10^{4}\right.$ cell. $\left.\mathrm{L}^{-1}\right)$ occur, but rarely when only cells of the D. acuminata complex are detected, in which case OA usually becomes the single diarrheic toxin present [32]. Similarly, in late summer 2015, one year before the event reported in this study, an extremely dense bloom of the Dinophysis acuminata complex affected the coast of Uruguay and only OA was detected by LC-MS/MS [32]. This further suggests that there may be interconnectivity between Uruguayan and southern Brazilian populations of the D. acuminata complex, perhaps driven by the northward transport of PWP from late summer to winter. This possibility remains to be addressed in future studies.

All marine organisms collected in the upper water layer $(0-1 \mathrm{~m})$ at the sampling site were consistently contaminated with varying amounts of OA. This is the first record of diarrheic toxin accumulation in amphipods (Caprellidae), shrimp (X. kroyeri), Nereidae polychaetes and blenny fish (Blenniedae). The only previous records of OA content in fish included carnivorous flounders, Platichthys flesus [33], and filter-feeding anchovies, Cetengraulis edentulus [32]. Results of the present study demonstrated that the combtooth blenny, Hypleurochilus fissicornis, can accumulate moderate OA levels in their viscera during Dinophysis blooms, but are able to rapidly eliminate the toxin. Therefore, this fish species may act as a temporary vector of diarrheic toxins for other species, including commercially important species of Serranidae and Lutjanidae, which prey upon small fish like blennies [62]. Hypleurochilus fissicornis is widely distributed in the southwest Atlantic; adults feed primarily on isopods and amphipods [63], that were likely an important-although probably not the sole-toxin source for the fish during the bloom, as the peak in OA levels occurred later for amphipods than for $H$. fissicornis in the present study. Amphipods accumulated relatively high OA levels (up to $\sim 150 \mu \mathrm{g} \mathrm{OA} \cdot \mathrm{Kg}^{-1}$ ) at the peak of the bloom. Although most amphipods are detritivores/scavengers, caprellids such as the ones sampled in our study are omnivorous and may feed not only on detritus, but also on microalgae, protozoans, smaller amphipods and crustacean larvae [64]. Caprellids are frequent and abundant organisms associated with suspended mussel farms, living on substrates such as mussel sleeves and ropes, and may thus be important toxin vectors to several organisms that search for shelter and food within the mussel longlines in aquaculture areas.

Mussels accumulated the greatest OA levels during the bloom, exceeding by 4-fold the $160-\mu \mathrm{g} \cdot \mathrm{Kg}^{-1}$ Brazilian regulatory seafood safety level [65]. Perna perna mussels are the sentinel species in HAB monitoring programs in Brazil and, like other mussel species, are able to rapidly incorporate high levels of several marine biotoxins and contaminants [66-70]. Indeed, along with barnacles, mussels were the only organisms exhibiting detectable OA levels during the entire sampling period. They consistently and promptly reflected the abundance of the D. acuminata complex (i.e., they attained maximum OA levels only one day after the peak in cell abundance). Considering the high Dinophysis cell abundance reported during this bloom, however, OA levels in P. perna were not as high as expected, what may be related to its fast toxin elimination rates as reported in previous laboratory experiments [21]. Besides mussels, non-edible polychaetes (P. palpata) and amphipods were the only organisms to accumulate total OA levels approaching or surpassing this regulatory level in the present study. Toxin contents in barnacles were 8 to $48 \times$ lower-and less clearly related to Dinophysis cell density-than those of mussels. Barnacles colonize hard substrates, rocks, bivalve shells and mooring 
structures, living in clusters of around a dozen individuals that actively capture food particles from the surrounding water [71]. In the present study, barnacles were collected from the shells of the same mussels sampled for OA analysis, so that the differential toxin accumulation reported here for these two suspension-feeding taxa can only be attributed to distinct feeding mechanisms and toxin uptake/elimination capacity. The consistently greater proportions of conjugated OA in mussels $(>90 \%)$ reflect their efficient mechanisms of toxin metabolism and elimination. Likewise, Caprellidae amphipods, small crabs (P. spinosissimus), shrimp (X. kroyeri) may have ingested toxins from the grazers or their organic matter produced [72,73], and carnivorous gastropods (S. haemastoma) also accumulated very limited to undetectable free-OA levels. This finding at least partly suggests that these organisms ingested already metabolized (i.e., conjugated) toxin, either incorporated into mussel and barnacle tissues (gastropods, shrimp and crabs) or from detrital origin (in the case of amphipods and crabs). High toxin levels were found in seston during this study and in particles $>60 \mu \mathrm{m}$ (L. Mafra, unpublished data), suggesting that not only Dinophysis cells but also toxin-containing organic particles and zooplankton organisms may contribute to the transfer of diarrheic toxins along the foodweb. Therefore, although zooplankton (e.g., copepods) may exert significant grazing impact and contribute considerably to control population growth of Dinophysis spp. [74], contaminated individuals will act as vectors of DSP-toxins to higher trophic levels.

Transfer of lipophilic toxins in the marine food web is still poorly understood. Although they represent only a small fraction of the sinking organic material, zooplankters such as the copepod Temora longicornis, might contribute in maintaining toxin availability for other organisms via production of toxic faecal pellets following ingestion of Dinophysis cells [73]. Inter- and intraspecific differences in the capacity of uptake and elimination of phycotoxins, as reported for suspension-feeding grazers such as oysters, clams and mussels [21,75-77], may ultimately determine the bioavailability of these compounds for other organisms during and after a bloom. In this study, polychaetes, which exhibited the highest proportions of free-OA and whose total OA levels continued to increase through the end of the sampling period, proved to be slow in eliminating OA. They may thus be an important toxin vector during late bloom stages, by prolonging toxin availability in the trophic web even after bloom termination.

To date, potential vectors of diarrheic toxins to human consumers have been restricted to several bivalve species (reviewed by FAO/WHO [78]), a couple of fish species [32,33], octopuses [20] and crabs $[34,35]$. The present study indicates that seabob shrimp (X. kroyeri) can represent a novel vector for toxin transfer to humans during massive dinoflagellate blooms. Although these shrimp accumulated the lowest OA levels $\left(\leq 7 \mu \mathrm{g} \cdot \mathrm{Kg}^{-1}\right)$ of all investigated faunal species and thus cannot be classified as a risk for acute food intoxication among seafood consumers, frequent consumers of this valuable fishery resource may be chronically exposed to low toxin levels during prolonged blooms. Seabob shrimp catches may reach 170 tons per year only in the Armação do Itapocoroy area [79], our study site, and the seabob shrimp fishing season coincides with the usual period of Dinophysis blooms in southern Brazil (winter to spring; [80]). Additionally, shrimp and, to some extent crabs and blenny fish, are highly motile. Their frequent vertical migration throughout the water column or on mussel ropes and sleeves may thus help to accelerate toxin transfer from pelagic to benthic compartments, and to spread diarrheic toxins over a more complex trophic web.

\section{Materials and Methods}

\subsection{Study Area}

Armação do Itapocoroy is a shallow [mean depth $=8 \mathrm{~m}$; maximum (max.) $=15 \mathrm{~m}$ ] inlet in Santa Catarina State, southern Brazil ( $26^{\circ} 47^{\prime} \mathrm{S}, 48^{\circ} 37^{\prime} \mathrm{W}$ ). Surrounded by hills (up to $250 \mathrm{~m}$ high), its geographic SE-NE orientation provides natural shelter from prevailing waves and winds, especially the stronger ones coming from the south. Due to these favorable attributes, Armação do Itapocoroy (Figure 6) harbors the major marine aquaculture ( $\sim 360$ hectares) operations in the country, mainly used 
for the cultivation of mussels, but also of oysters and scallops. The location experiences semi-diurnal, micro-tidal cycles and is affected by the Itajaí-Açu River plume, that maintains high levels of local primary production and brings high loads of suspended particulate matter (SPM) mainly during rainy periods such as the austral summer (December-March) [81-83].

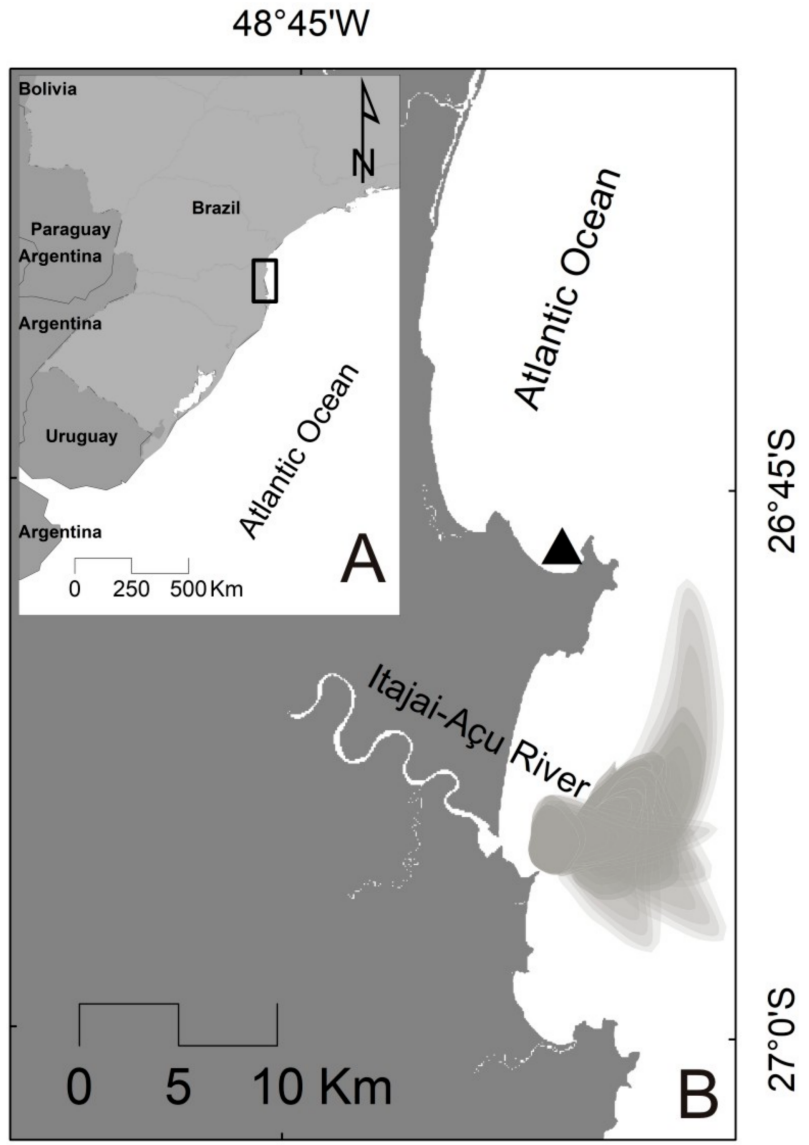

Figure 6. Map showing the location of the study area, Armação do Itapocoroy inlet (triangle in (B)), on the southern coast of Brazil (rectangle in (A)). A schematic representation of the prevailing direction and influence area of the Itajaí-Açu River plume is also presented, based on Trochimczuk-Fo and Schettini (2003) [83].

\subsection{Sampling Design}

An intensive sampling effort was conducted between late May and mid-June 2016, when the Santa Catarina coastal zone was affected by a dense Dinophysis bloom. Seawater sampling was carried out from a floating platform, anchored at a depth of $4.5 \pm 0.5 \mathrm{~m}$ and deployed $200 \mathrm{~m}$ from the low tide level. Samples $(1.5 \mathrm{~L})$ were taken every meter along a vertical profile, from the surface to the bottom, using an EN-470 manual diaphragm pump (Emifran ${ }^{\circledR}$, São Paulo, SP, Brazil) equipped with anti-reflux valves and coupled to a $20 \mathrm{~mm}$-diameter hose. Daily samples were taken over 12 days, followed by two sampling operations after 3- and 10-day intervals of the 12th sampling day. Additionally, single depth-integrated water samples $(2.0 \mathrm{~L})$ were taken with a $5 \mathrm{~m}$ long hose, to compare the efficiency of both sampling strategies for monitoring of extreme bloom events. Plankton net (20- $\mu \mathrm{m}$ mesh size) samples were also collected, and water temperature and salinity were measured along a vertical profile, at $0.5 \mathrm{~m}$ intervals from surface to bottom, using a multiparameter YSI Professional Plus probe. Secchi depth was used to estimate water column light penetration or transparency.

In parallel, bivalve mollusks (Perna perna; $n>5$ ), gastropods (Stramonita haemastoma; $n>2$ ), barnacles (Megabalanus tintinnabulum; $n>10$ ), amphipods (Caprellidae; 10 g of wet weight), crabs 
(Pilumnus spinosissimus; $n>3$ ), shrimp (Xiphopenaeus kroyeri; $n>5$ ), polychaetes (Pseudonereis palpate; $n>3$ ) and fish (Hypleurochilus fissicornis-Blenniidae; $n>2$ ) were manually collected from raft mooring cables at $0-1 \mathrm{~m}$ depth, for quantification of the toxin levels incorporated in their tissues. The species collected and sampling frequency depended on their availability in the environment during the study period. Whenever possible, at least two individuals of each species were collected, packed in $50 \mathrm{~mL}$ plastic tubes and immediately immersed in an ice bath until return to the laboratory. Before freezing, soft tissues of mussels, barnacles and gastropods were removed from their shells. Fish muscles (flesh) and viscera were dissected and individually stored at $-18{ }^{\circ} \mathrm{C}$. The remaining organisms were frozen and analyzed whole.

\subsection{Processing of Samples}

Water samples: Aliquots $(300 \mathrm{~mL})$ of both depth-discrete and integrated samples were fixed with $1 \%$ Lugol's iodine solution, and used for quantitative phytoplankton analysis. Plankton net samples, fixed with a $4 \%$ formalin solution (final concentration), were used for analysis of cell morphology and phytoplankton identification. In the laboratory, additional $300 \mathrm{~mL}$ aliquots of each sample were gently vacuum-filtered in duplicate and immediately frozen. One fiberglass filter (Marcherey-Nagel ${ }^{\circledR}$, Düren, Germany, model 85/70BF; $47 \mathrm{~mm}$ diameter and $0.45 \mu \mathrm{m}$ nominal retention capacity) was allocated for the analysis of photosynthetic pigments, and the second one to determine the amount of lipophilic toxins contained in SPM. In an ice bath, each filter sample was soaked in HPLC grade methanol (99.5\%) and exposed to an ultra-sonic probe (Cole Parmer, Vernon Hills, IL, USA, CPX130) for $30 \mathrm{~s}$. The extract was then passed through a $13 \mathrm{~mm} \times 0.22 \mu \mathrm{m}$ PVDF syringe filter (Analitica ${ }^{\circledR}$, São Paulo, SP, Brazil) to remove any cell debris, and the filtrate collected into plastic microtubes $(1.5 \mathrm{~mL})$, which were maintained frozen. Aliquots $(400 \mathrm{~mL})$ of the filtrate from depth-integrated samples collected from 1 May on were stored frozen in plastic bottles for future spectrophotometric determination of dissolved inorganic nutrient (DIN) concentrations.

Samples of marine fauna: The protocol for toxin extraction was adapted from the official analytical method harmonized by the European Union [84]. Methanol (99.5\%; HPLC grade) was added in the ratio of 1:9 (v:v) to $1.0 \pm 0.5 \mathrm{~g}$ of homogenate from selected tissues or whole body, exposed to an ultra-sonic probe (Cole Parmer, CPX130) until complete tissue disruption, and centrifuged at $2000 \times g$ for $10 \mathrm{~min}$. The supernatant was filtered through a $0.22-\mu \mathrm{m}$ syringe filter directly into a $2.0 \mathrm{~mL}$ glass vial, and kept frozen for the analysis of diarrheic toxins in their free form. Subsequently, $1 \mathrm{~mL}$ aliquots of the extract were subjected to alkaline hydrolysis by the addition of $2.5 \mathrm{M}$ sodium hydroxide in a $76^{\circ} \mathrm{C}$ thermal bath for $40 \mathrm{~min}$, followed by the addition of $2.5 \mathrm{M}$ hydrochloric acid to neutralize the solution and convert the conjugated (metabolized) toxins into their free toxin forms. The amount of conjugated toxins was obtained by subtracting the concentration of free toxins initially measured in the non-hydrolyzed extract from the total concentration of toxins obtained in the hydrolyzed extract.

\subsection{Phytoplankton Identification and Enumeration}

Counting of Dinophysis spp. and M. cf. rubrum cells was performed using a $20 \mathrm{~mL}$ aliquot of the Lugol-fixed sample, after settling the particles for $24 \mathrm{~h}$ in a Utermöhl chamber [85]. Cell counting was then performed by scanning the whole chamber under an inverted optical microscope at $200 \times$ magnification (limit of detection, LOD: 50 cell $\cdot \mathrm{L}^{-1}$ ). Other phytoplankton groups (total cryptophytes, diatoms, and dinoflagellates) were quantified in volumes ranging from 10 to $20 \mathrm{~mL}$ (depending on sample turbidity) by counting all cells contained in 5-10 random microscope fields of view (LOD: $2100-8400$ cell $\cdot \mathrm{L}^{-1}$ ) after 24-h settlement. Additionally, a minimum of 100 cells of Dinophysis spp. were picked with a micropipette from in natura plankton net samples at the bloom apex ( 2 and 3 June; $n=5$ samples each day), and placed into $1.5 \mathrm{~mL}$ plastic microtubes containing methanol 99.5\% (HPLC grade) for determination of the toxin cellular quota. 


\subsection{Spectrophotometric Analysis of Dissolved Inorganic Nutrients}

Aliquots $(25 \mathrm{~mL})$ of the filtrate samples were used to determine the concentrations of phosphate $\left(\mathrm{P}-\mathrm{PO}_{4}{ }^{3-}\right)$, nitrite $\left(\mathrm{N}-\mathrm{NO}_{2}{ }^{-}\right)$, nitrate $\left(\mathrm{N}-\mathrm{NO}_{3}{ }^{-}\right)$, ammonium $\left(\mathrm{N}-\mathrm{NH}_{4}{ }^{+}\right)$, and silicate $\left(\mathrm{SiO}_{2}{ }^{-}\right)$using colorimetric methods [86]. The concentrations were determined from a linear regression obtained from successive dilutions of the respective analytical standards (coefficient of determination, $r^{2}>0.90$ ).

\subsection{Analysis of Photosynthetic Pigments by LC-DAD}

The methanolic extracts were injected $(100 \mu \mathrm{L})$ into a Chromaster liquid chromatography (LC) system (Hitachi ${ }^{\circledR}$, Tokyo, Japan), composed of a quaternary gradient pump, an automatic thermostat injector, a column oven (set at $40{ }^{\circ} \mathrm{C}$ ) and a photodiode detector (DAD). Samples were eluted in a mixture of (A) methanol:acetone:pyridine (50:25:25) and (B) acetonitrile:acetone (80:20), at $1.0 \mathrm{~mL} \cdot \mathrm{min}^{-1}$. The proportion of B increased from 0 to $40 \%$ in $18 \mathrm{~min}$, and then to $100 \%$ within the following $4 \mathrm{~min}$ of analysis, remaining at $100 \%$ for an extra $16 \mathrm{~min}$ before returning to the initial conditions ( $0 \%$ B) for an additional $2 \mathrm{~min}$ period (40 $\mathrm{min}$ in total). Pigment identification was performed by evaluating retention times after the chromatographic separation in a Waters Symmetry ${ }^{\circledR}$

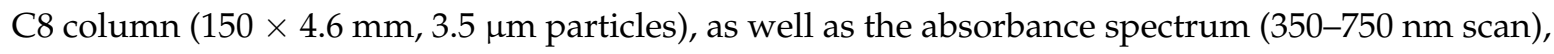
following methods of Zapata et al. [87]. The chlorophyll- $a$ (chl- $a$ ) concentration was calculated using a linear regression obtained from successive dilutions of the analytical standard (Sigma-Aldrich, Saint Louis, MO, USA) $\left(0.78,1.56,3.12,6.25,12.50\right.$, and $\left.25.00 \mathrm{ng} \cdot \mathrm{mL}^{-1}\right)$ with $r^{2}>0.98$.

\subsection{Analysis of Diarrheic Toxins by LC-MS/MS}

Toxins were measured using a 1260 LC system (Agilent Technologies ${ }^{\circledR}$, Santa Clara, CA, USA) coupled to a triple quadrupole mass spectrometer, MS (AB Scie ${ }^{\circledR}$, Framingham, MA, USA, qTRAP 3200) equipped with a turbo ion spray ionization source, following the EURLMB protocol [84]. Briefly, 5 to $15 \mu \mathrm{L}$ of each sample were eluted by the mobile phase, consisting of a mixture of (A) $100 \%$ ultra-pure water and (B) $95 \%$ acetonitrile, both with the addition of ammonium formate $(2 \mathrm{mM})$ and formic acid $(50 \mathrm{mM})$. At a $0.3 \mathrm{~mL} \cdot \mathrm{min}^{-1}$ flow rate, the initial proportion of $80: 20 \%$ (A:B) increased to $100 \% \mathrm{~B}$ during the first $8 \mathrm{~min}$ of analysis, thus remaining for $3.5 \mathrm{~min}$, and returning to the initial condition by the end of the analysis (13 min). Compounds were separated on a C18 column (Agilent Poroshell ${ }^{\circledR}$, Santa Clara, CA, USA, $50 \times 2.1 \mathrm{~mm}, 2.7 \mu \mathrm{m}$ particles), maintained at $20^{\circ} \mathrm{C}$. Identification of individual toxins was achieved from their retention time and the mass spectra of the transition ions present in the samples in relation to the same parameters obtained for the analytical standards. High-purity nitrogen, heated up to $500{ }^{\circ} \mathrm{C}$, was used as the nebulizing gas. The electron spray (ESI) ion source operated in negative mode, and toxins were scanned for transition ions $(\mathrm{Q} 1 \rightarrow \mathrm{Q} 3)$ of characteristic mass/charge $(\mathrm{m} / \mathrm{z})$ ratios. Optimized MS parameters were selected for each toxin of interest (Table 1).

Table 1. Conditions of the tandem mass spectrometry system (MS/MS). Q1: quadrupole 1, Q3: quadrupole 3, DP: declustering potential, EP: entrance potential, CEP: collision cell entrance potential, CE: collision energy and CXP: collision cell exit potential.

\begin{tabular}{cccccccc}
\hline Toxins & Q1 $(\boldsymbol{m} / \boldsymbol{z})$ & $\mathbf{Q} \mathbf{( m / z )}$ & $\mathbf{D P}(\mathbf{v})$ & $\mathbf{E P}(\mathbf{v})$ & $\mathbf{C E P}(\mathbf{v})$ & $\mathbf{C E}(\mathbf{v})$ & $\mathbf{C X P}(\mathbf{v})$ \\
\hline OA & 803.5 & 255.0 & -129 & -10 & -40.1 & -82 & -2 \\
OA & 803.5 & 113.0 & -129 & -10 & -41.5 & -64 & -2 \\
DTX-2 & 803.5 & 255.0 & -129 & -10 & -40.6 & -64 & -2 \\
DTX-2 & 803.5 & 113.0 & -129 & -10 & -41.5 & -84 & -2 \\
DTX-1 & 817.5 & 255.0 & -129 & -10 & -41.5 & -62 & -2 \\
DTX-1 & 817.5 & 113.0 & -120 & -10 & -51.7 & -82 & -2 \\
DTX-3 & 1041.6 & 255.0 & -129 & -10 & -47.9 & -76 & -2 \\
\hline
\end{tabular}


Toxin quantification was carried out using an external standard from a calibration curve generated with certified reference material (IMB-NRC, Canada) dissolved in methanol for OA, and in mussel tissue matrix (CRM-DSP-Mus-b) for DTX-1. Quantification of OA was based on the equation obtained by fitting a linear regression $\left(r^{2}>0.95\right)$ to the following concentrations: $3.49,13.96,55.86$, and $223.44 \mathrm{ng} \cdot \mathrm{mL}^{-1}$.

\subsection{Data Analysis}

Graphs were constructed in SigmaPlot ${ }^{\circledR}$ v11.0 (Systat Software Inc., London, UK), using the statistical package for preliminary analysis. Data were statistically analyzed with R studio software [88], using the Kruskal-Wallis non-parametric test $(\mathrm{H})$ followed by the Dunn test (with the software package dunn.test; [89]) for comparative analyses within and among water column depths, between discrete and integrated samples, and for analysis of temporal variation. Principal components analysis (PCA) (with the FactoMiner package; [90]) allowed quantification of the degree of association among water temperature, Secchi depth, salinity, numerical abundance of main taxonomic groups, concentration of dissolved inorganic nutrients and seston toxin content.

Author Contributions: Both authors contributed equally to the study conceptualization, sampling design, LC-MS/MS analysis and manuscript writing; T.P.A. conducted the sampling, plankton analysis, toxin extraction and carried out the data analysis; L.L.M.J. supervised the activities, administrated the project and acquired funding.

Acknowledgments: The authors thank the bivalve growers affiliated with the Association of Marine Farmers of Paulas (AMAP), and personnel involved in HAB monitoring programs in Santa Catarina State, including those from the Agricultural Research and Rural Extension Company of Santa Catarina (EPAGRI), Integrated Company of Agricultural Development Santa Catarina (CIDASC), and the Agricultural and Livestock Defense Secretary (SDA) of the Ministry of Agriculture, Livestock and Food Supply (MAPA). This study was partially funded by CNPq (Grant \# 610012/2011-8) through the Brazilian National Institute of Science and Technology (INCT-Mar-COI).

Conflicts of Interest: The authors declare no conflict of interest.

\section{References}

1. Reguera, B.; Velo-Suárez, L.; Raine, R.; Park, M.G. Harmful Dinophysis species: A review. Harmful Algae 2012, 14, 87-106. [CrossRef]

2. García-Altares, M.; Casanova, A.; Fernández-Tejedor, M.; Diogène, J.; de la Iglesia, P. Bloom of Dinophysis spp. dominated by D. sacculus and its related diarrhetic shellfish poisoning (DSP) outbreak in Alfacs Bay (Catalonia, NW Mediterranean Sea): Identification of DSP toxins in phytoplankton, shellfish and passive samplers. Reg. Stud. Mar. Sci. 2016, 6, 19-28. [CrossRef]

3. Whyte, C.; Swan, S.; Davidson, K. Changing wind patterns linked to unusually high Dinophysis blooms around the Shetland Islands, Scotland. Harmful Algae 2014, 39, 365-373. [CrossRef]

4. Pitcher, G.C.; Krock, B.; Cembella, A.D. Accumulation of diarrhetic shellfish poisoning toxins in the oyster Crassostrea gigas and the mussel Choromytilus meridionalis in the southern Benguela ecosystem. Afr. J. Mar. Sci. 2011, 33, 273-281. [CrossRef]

5. Aissaoui, A.; Dhib, A.; Reguera, B.; Ben Hassine, O.K.; Turki, S.; Aleya, L. First evidence of cell deformation occurrence during a Dinophysis bloom along the shores of the Gulf of Tunis (SW Mediterranean Sea). Harmful Algae 2014, 39, 191-201. [CrossRef]

6. Li, A.; Sun, G.; Qiu, J.; Fan, L. Lipophilic shellfish toxins in Dinophysis caudata picked cells and in shellfish from the East China Sea. Environ. Sci. Pollut. Res. 2015, 22, 3116-3126. [CrossRef] [PubMed]

7. Hattenrath-Lehmann, T.K.; Marcoval, M.A.; Berry, D.L.; Fire, S.; Wang, Z.; Morton, S.L.; Gobler, C.J. The emergence of Dinophysis acuminata blooms and DSP toxins in shellfish in New York waters. Harmful Algae 2013, 26, 33-44. [CrossRef]

8. Martínez, A.; Nacional, D.; Acuáticos, D.R.; Fabre, A. Intensification of marine dinoflagellates blooms in Uruguay Intensificación de floraciones de dinoflagelados marinos en Uruguay Intensification of marine dinoflagellates blooms in Uruguay. Rev. Lab. Tecnol. Urug. 2017, 13, 19-25.

9. Sar, E.A.; Sunesen, I.; Goya, A.B.; Lavigne, A.S.; Tapia, E.; García, C.; Lagos, N. First Report of Diarrheic Shellfish Toxins in Mollusks from Buenos Aires Province (Argentina) associated with Dinophysis spp.: Evidence os okadaic acid, dinophysistoxin-1 and their acyl-derivates. Biol. Soc. Argent. Bot. 2012, 47, 5-14. 
10. Villalobos, L.G.; Santinelli, N.; Sastre, V.; Krock, B.; Esteves, J.L. Dinophysis Species Associated with Diarrhetic Shellfish Poisoning Episodes in North Patagonian Gulfs (Chubut, Argentina). J. Shellfish Res. 2015, 34, 1141-1149. [CrossRef]

11. Smayda, T.J. Complexity in the eutrophication-harmful algal bloom relationship, with comment on the importance of grazing. Harmful Algae 2008, 8, 140-151. [CrossRef]

12. Lewitus, A.J.; Brock, L.M.; Burke, M.K.; DeMattio, K.A.; Wilde, S.B. Lagoonal stormwater detention ponds as promoters of harmful algal blooms and eutrophication along the South Carolina coast. Harmful Algae 2008, 8, 60-65. [CrossRef]

13. Heisler, J.; Glibert, P.M.; Burkholder, J.M.; Anderson, D.M.; Cochlan, W.; Dennison, W.C.; Dortch, Q.; Gobler, C.J.; Heil, C.A.; Humphries, E.; et al. Eutrophication and harmful algal blooms: A scientific consensus. Harmful Algae 2008, 8, 3-13. [CrossRef] [PubMed]

14. Buskey, E.J. How does eutrophication affect the role of grazers in harmful algal bloom dynamics? Harmful Algae 2008, 8, 152-157. [CrossRef]

15. Hallegraeff, G.M. Ocean climate change, phytoplankton community responses, and harmful algal blooms: A formidable predictive challenge. J. Phycol. 2010, 46, 220-235. [CrossRef]

16. O'Neil, J.M.; Davis, T.W.; Burford, M.A.; Gobler, C.J. The rise of harmful cyanobacteria blooms: The potential roles of eutrophication and climate change. Harmful Algae 2012, 14, 313-334. [CrossRef]

17. Haraguchi, L.; Odebrecht, C. Dinophysiales (Dinophyceae) no extremo Sul do Brasil (inverno de 2005, verão de 2007). Biota Neotrop. 2010, 10, 101-114. [CrossRef]

18. Proença, L.A.O.; Schramm, M.A.; da Silva Tamanaha, M.; Alves, T.P. Diarrhoetic shellfish poisoning (DSP) outbreak in Subtropical Southwest Atlantic. Harmful Algae News 2007, 1-28.

19. Rosa, C.M.A.; Philippi, J.M.S. Perfil epidemiologico de surtos de DTA por moluscos bivalves em Santa Catarina, Brasil, em 2007 e 2008. Hig. Aliment. 2009, 23, 570.

20. Mafra, L.L.; Lopes, D.; Bonilauri, V.C.; Uchida, H.; Suzuki, T. Persistent Contamination of Octopuses and Mussels with Lipophilic Shellfish Toxins during Spring Dinophysis Blooms in a Subtropical Estuary. Mar. Drugs. 2015, 13, 3920-3935. [CrossRef] [PubMed]

21. Mafra, L.L.; Ribas, T.; Alves, T.P.; Proença, L.A.O.; Schramm, M.A.; Uchida, H.; Suzuki, T. Differential okadaic acid accumulation and detoxification by oysters and mussels during natural and simulated Dinophysis blooms. Fish. Sci. 2015, 81, 749-762. [CrossRef]

22. Proença, L.A.; Schmitt, F.; Costa, T.; Rorig, L. Evidences of diarrhetic shellfish poisoning in Santa Catarina-Brazil. J. Braz. Assoc. Advant. Sci. 1998, 50, 459-462.

23. BRASIL. Instrução Normativa Interministerial 7 de 8 de Maio de 2012; Governo do Estado do Tocantins: Brasília, Brasil, 2012; pp. 55-59.

24. Reguera, B.; Riobó, P.; Rodríguez, F.; Díaz, P.A.; Pizarro, G.; Paz, B.; Franco, J.M.; Blanco, J. Dinophysis toxins: Causative organisms, distribution and fate in shellfish. Mar. Drugs. 2014, 12, 394-461. [CrossRef] [PubMed]

25. Moita, M.T.; Pazos, Y.; Rocha, C.; Nolasco, R.; Oliveira, P.B. Toward predicting Dinophysis blooms off NW Iberia: A decade of events. Harmful Algae 2016, 53, 17-32. [CrossRef] [PubMed]

26. Kim, M.; Nam, S.W.; Shin, W.; Coats, D.W.; Park, M.G. Dinophysis caudata (dinophyceae) sequesters and retains plastids from the mixotrophic ciliate prey Mesodinium rubrum. J. Phycol. 2012, 48, 569-579. [CrossRef] [PubMed]

27. Giménez Papiol, G.; Beuzenberg, V.; Selwood, A.I.; MacKenzie, L.; Packer, M.A. The use of a mucus trap by Dinophysis acuta for the capture of Mesodinium rubrum prey under culture conditions. Harmful Algae 2016, 58, 1-7. [CrossRef] [PubMed]

28. Mafra, L.L.; Nagai, S.; Uchida, H.; Tavares, C.P.S.; Escobar, B.P.; Suzuki, T. Harmful effects of Dinophysis to the ciliate Mesodinium rubrum: Implications for prey capture. Harmful Algae 2016, 59, 82-90. [CrossRef] [PubMed]

29. Ojamäe, K.; Hansen, P.J.; Lips, I. Mass entrapment and lysis of Mesodinium rubrum cells in mucus threads observed in cultures with Dinophysis. Harmful Algae 2016, 55, 77-84. [CrossRef] [PubMed]

30. Jiang, T.J.; Wang, D.Z.; Niu, T.; Xu, Y.X. Trophic transfer of paralytic shellfish toxins from the cladoceran (Moina mongolica) to larvae of the fish (Sciaenops ocellatus). Toxicon 2007, 50, 639-645. [CrossRef] [PubMed]

31. Reizopoulou, S.; Strogyloudi, E.; Giannakourou, A.; Pagou, K.; Hatzianestis, I.; Pyrgaki, C.; Granéli, E. Okadaic acid accumulation in macrofilter feeders subjected to natural blooms of Dinophysis acuminata. Harmful Algae 2008, 7, 228-234. [CrossRef] 
32. Mafra, L.L.; dos Santos Tavares, C.P.; Schramm, M.A. Diarrheic toxins in field-sampled and cultivated Dinophysis spp. cells from southern Brazil. J. Appl. Phycol. 2014, 26, 1727-1739. [CrossRef]

33. Sipiä, V.; Kankaanpää, H.; Meriluoto, J.; Høisæter, T. The first observation of okadaic acid in flounder in the Baltic Sea. Sarsia. 2000, 85, 471-475. [CrossRef]

34. Jiang, T.J.; Niu, T.; Xu, Y.X. Transfer and metabolism of paralytic shellfish poisoning from scallop (Chlamys nobilis) to spiny lobster (Panulirus stimpsoni). Toxicon 2006, 48, 988-994. [CrossRef] [PubMed]

35. Vale, P.; Sampayo, M.A.D.M. First confirmation of human diarrhoeic poisonings by okadaic acid esters after ingestion of razor clams (Solen marginatus) and green crabs (Carcinus maenas) in Aveiro lagoon, Portugal and detection of okadaic acid esters in phytoplankton. Toxicon 2002, 40, 989-996. [CrossRef]

36. Hernández, M.; Robinson, I.; Aguilar, A.; González, L.M.; López-Jurado, L.F.; Reyero, M.I.; Cacho, E.; Franco, J.; López-Rodas, V.; Costas, E. Did algal toxins cause monk seal mortality? Nature 1998, 393, $28-29$. [CrossRef] [PubMed]

37. Mafra, L.L.; Nolli, P.K.; Luz, L.F.; Leal, J.G.; Sobrinho, B.F.; Pimenta, B.; Escobar; Juraczky, L.; Gonzalez, A.R.M.; Mota, L.E.; et al. Okadaic acid contamination during an exceptionally massive Dinophysis cf. acuminata bloom in southern Brazil. In Proceedings of the Abstracts of the 17th International Conference of Harmful Algae, Florianópolis, Brazil, 9-14 October 2016; p. 212.

38. Díaz, P.; Molinet, C.; Cáceres, M.A.; Valle-Levinson, A. Seasonal and intratidal distribution of Dinophysis spp. in a Chilean fjord. Harmful Algae 2011, 10, 155-164. [CrossRef]

39. Alves-de-Souza, C.; Varela, D.; Contreras, C.; de La Iglesia, P.; Fernández, P.; Hipp, B.; Hernández, C.; Riobó, P.; Reguera, B.; Franco, J.M.; et al. Seasonal variability of Dinophysis spp. and Protoceratium reticulatum associated to lipophilic shellfish toxins in a strongly stratified Chilean fjord. Deep. Res. Part II Top. Stud. Oceanogr. 2014, 101, 152-162. [CrossRef]

40. Aissaoui, A.; Armi, Z.; Turki, S.; Hassine, O.K. Ben Seasonal dynamic and in situ division rates of the dominant Dinophysis species in Punic harbors of Carthage (Gulf of Tunis, South Mediterranean). Environ. Monit. Assess. 2013, 185, 9361-9384. [CrossRef] [PubMed]

41. Van den Hoff, J.; Bell, E. The ciliate Mesodinium rubrum and its cryptophyte prey in Antarctic aquatic environments. Polar Biol. 2015, 38, 1305-1310. [CrossRef]

42. Crawford, D.W.; Lindholm, T. Some observations on vertical distribution and migration of the phototrophic ciliate Mesodinium rubrum (=Myrionecta rubra) in a stratified brackish inlet. Aquat. Microb. Ecol. 1997, 13, 267-274. [CrossRef]

43. Johnson, M.D.; Stoecker, D.K.; Marshall, H.G. Seasonal dynamics of Mesodinium rubrum in Chesapeake Bay. J. Plankton Res. 2013, 35, 877-893. [CrossRef]

44. Kim, M.; Kim, S.; Yih, W.; Park, M.G. The marine dinoflagellate genus Dinophysis can retain plastids of multiple algal origins at the same time. Harmful Algae 2012, 13, 105-111. [CrossRef]

45. Stern, R.F.; Amorim, A.L.; Bresnan, E. Diversity and plastid types in Dinophysis acuminata complex (Dinophyceae) in Scottish waters. Harmful Algae 2014, 39, 223-231. [CrossRef]

46. Wisecaver, J.H.; Hackett, J.D. Transcriptome analysis reveals nuclear-encoded proteins for the maintenance of temporary plastids in the dinoflagellate Dinophysis acuminata. BMC Genom. 2010, 11, 366. [CrossRef] [PubMed]

47. Kim, M.; Nam, S.W.; Shin, W.; Coats, D.W.; Park, M.G. Fate of green plastids in Dinophysis caudata following ingestion of the benthic ciliate Mesodinium coatsi: Ultrastructure and psbA gene. Harmful Algae 2015, 43, 66-73. [CrossRef]

48. Lindahl, O.; Lundve, B.; Johansen, M. Toxicity of Dinophysis spp. in relation to population density and environmental conditions on the Swedish west coast. Harmful Algae 2007, 6, 218-231. [CrossRef]

49. Raine, R. A review of the biophysical interactions relevant to the promotion of HABs in stratified systems: The case study of Ireland. Deep. Res. Part II Top. Stud. Oceanogr. 2014, 101, 21-31. [CrossRef]

50. Koukaras, K. Dinophysis blooms in Greek coastal waters (Thermaikos Gulf, NW Aegean Sea). J. Plankton Res. 2004, 26, 445-457. [CrossRef]

51. Fabro, E.; Almandoz, G.O.; Ferrario, M.E.; Hoffmeyer, M.S.; Pettigrosso, R.E.; Uibrig, R.; Krock, B. Co-occurrence of Dinophysis tripos and pectenotoxins in Argentinean shelf waters. Harmful Algae 2015, 42, 25-33. [CrossRef]

52. Möller, O.O.; Piola, A.R.; Freitas, A.C.; Campos, E.J.D. The effects of river discharge and seasonal winds on the shelf off southeastern South America. Cont. Shelf Res. 2008, 28, 1607-1624. [CrossRef] 
53. Piola, A.R.; Romero, S.I.; Zajaczkovski, U. Space-time variability of the Plata plume inferred from ocean color. Cont. Shelf Res. 2008, 28, 1556-1567. [CrossRef]

54. Méndez, S.; Martínez, A.; Fabre, A. Extreme abundant bloom of Dinophysis ovum associated to positive SST anomalies in Uruguay. In Proceedings of the 17th International Conference of Harmful Algae, Florianópolis, Brazil, 9-14 October 2016; Proença, L.A.O., Hallegraeff, G.M., Eds.; International Society for the Study of Harmful Algae: Florianópolis, Brazil, 2016; pp. 22-25.

55. Méndez, S.; Rodriguez, F.; Reguera, B.; Franco, J.M.; Riobo, P.; Fabre, A. Characterization of Dinophysis ovum as the causative agent of the exceptional DSP event in Uruguay during 2015. In Proceedings of the 17th International Conference on Harmful Algae, Florianópolis, Brazil, 9-14 October 2016; Proença, L.A.O., Hallegraeff, G.M., Eds.; International Society for the Study of Harmful Algae: Florianópolis, Brazil, 2016; pp. 26-29.

56. Proença, L.A.O. Clorofila a do fitoplâncton em seis enseadas utilizadas para o cultivo de moluscos bivalves no litoral de Santa Catarina. Braz. J. Aquat. Sci. Technol. 2002, 6, 33-44. [CrossRef]

57. Ferreira, J.F.; Besen, K.; Wormsbecher, A.G.; Santos, R.F. Physical-Chemical Parameters of Seawater Mollusc Culture Sites in Santa Catarina-Brazil. J. Coast. Res. 2006, 1122-1126.

58. Escalera, L.; Pazos, Y.; Doval, M.D.; Reguera, B. A comparison of integrated and discrete depth sampling for monitoring toxic species of Dinophysis. Mar. Pollut. Bull. 2012, 64, 106-113. [CrossRef] [PubMed]

59. Farrell, H.; Gentien, P.; Fernand, L.; Lunven, M.; Reguera, B.; González-Gil, S.; Raine, R. Scales characterising a high density thin layer of Dinophysis acuta Ehrenberg and its transport within a coastal jet. Harmful Algae 2012, 15, 36-46. [CrossRef]

60. Aune, T.; Larsen, S.; Aasen, J.A.B.; Rehmann, N.; Satake, M.; Hess, P. Relative toxicity of dinophysistoxin-2 (DTX-2) compared with okadaic acid, based on acute intraperitoneal toxicity in mice. Toxicon 2007, 49, 1-7. [CrossRef] [PubMed]

61. Blanco, J.; Álvarez, G.; Uribe, E. Identification of pectenotoxins in plankton, filter feeders, and isolated cells of a Dinophysis acuminata with an atypical toxin profile, from Chile. Toxicon 2007, 49, 710-716. [CrossRef] [PubMed]

62. Froese, R.; Pauly, D. FishBase. Available online: http:/ / fishbase.org (accessed on 25 January 2018).

63. Menezes, N.A.; Figueiredo, J.L. Manual de Peixes Marinhos do Sudeste do Brasil. V. Teleostei (4); University of São Paulo: São Paulo, Brasil, 1985.

64. Caine, E.A. Caprellid amphipods: fast food for the reproductively active. J. Exp. Mar. Bio. Ecol. 1991, 148, 27-33. [CrossRef]

65. Brasil. Portaria No 204, de 28 de Junho de 2012; Ministério da Pesca e Aquicultura: Brasília-DF, Brazil, 2012; pp. 2-5.

66. Penna, A.; Bertozzini, E.; Battocchi, C.; Galluzzi, L.; Giacobbe, M.G.; Vila, M.; Garces, E.; Luglie, A.; Magnani, M. Monitoring of HAB species in the Mediterranean Sea through molecular methods. J. Plankton Res. 2006, 29, 19-38. [CrossRef]

67. Higman, W.A.; Algoet, M.; Stubbs, B.; Lees, D. Overview of developments of the algal biotoxin monitoring programme in England, Scotland and Wales. In Proceedings of the 6th International Conference on Molluscan Shellfish Safety, Blenheim, Marlborough, New Zealand, 18-23 March 2007; pp. 41-45.

68. Vale, P.; Botelho, M.J.; Rodrigues, S.M.; Gomes, S.S.; Sampayo, M.A.D.M. Two decades of marine biotoxin monitoring in bivalves from Portugal (1986-2006): A review of exposure assessment. Harmful Algae 2008, 7, 11-25. [CrossRef]

69. Brooks, S.; Harman, C.; Soto, M.; Cancio, I.; Glette, T.; Marigómez, I. Integrated coastal monitoring of a gas processing plant using native and caged mussels. Sci. Total Environ. 2012, 426, 375-386. [CrossRef] [PubMed]

70. Trainer, V.L.; Hardy, F.J. Integrative monitoring of marine and freshwater harmful algae in Washington State for public health protection. Toxins. 2015, 7, 1206-1234. [CrossRef] [PubMed]

71. Doyle, P.; Mather, A.E.; Bennett, M.R.; Bussell, M.A. Miocene barnacle assemblages from southern Spain and their palaeoenvironmental significance. Lethaia 1996, 29, 267-274. [CrossRef]

72. Turner, J.T. Planktonic marine copepods and harmful algae. Harmful Algae 2014, 32, 81-93. [CrossRef]

73. Maneiro, I.; Guisande, C.; Frangópulos, M.; Riveiro, I. Importance of copepod faecal pellets to the fate of the DSP toxins produced by Dinophysis spp. Harmful Algae 2002, 1, 333-341. [CrossRef] 
74. Kozlowsky-Suzuki, B.; Carlsson, P.; Rühl, A.; Granéli, E. Food selectivity and grazing impact on toxic Dinophysis spp. by copepods feeding on natural plankton assemblages. Harmful Algae 2006, 5, 57-68. [CrossRef]

75. Armi, Z.; Turki, S.; Trabelsi, E.; Ceredi, A.; Riccardi, E.; Milandri, A. Occurrence of diarrhetic shellfish poisoning (DSP) toxins in clams (Ruditapes decussatus) from Tunis north lagoon. Environ. Monit. Assess. 2012, 184, 5085-5095. [CrossRef] [PubMed]

76. Dumbauld, B.R.; Ruesink, J.L.; Rumrill, S.S. The ecological role of bivalve shellfish aquaculture in the estuarine environment: A review with application to oyster and clam culture in West Coast (USA) estuaries. Aquaculture. 2009, 290, 196-223. [CrossRef]

77. García-Mendoza, E.; Sánchez-Bravo, Y.A.; Turner, A.; Blanco, J.; O’Neil, A.; Mancera-Flores, J.; Pérez-Brunius, P.; Rivas, D.; Almazán-Becerril, A.; Peña-Manjarrez, J.L. Lipophilic toxins in cultivated mussels (Mytilus galloprovincialis) from Baja California, Mexico. Toxicon 2014, 90, 111-123. [CrossRef] [PubMed]

78. Food and Agriculture Organization of the United Nations (FAO); World Health Organization (WHO). Technical Paper on Toxicity Equivalency Factors for Marine Biotoxins Associated with Bivalve Molluscs; FAO: Roman, Italy; WHO: Geneva, Switzerland, 2016.

79. Branco, J.O. Biologia e pesca do camarão sete-barbas Xiphopenaeus kroyeri (Heller) (Crustacea, Penaeidae), na Armação do Itapocoroy, Penha, Santa Catarina, Brasil. Rev. Bras. Zool. 2005, 22, 1050-1062. [CrossRef]

80. Alves, T.P.; Schramm, M.A.; Proença, L.A.O.; Pinto, T.O.; Mafra, L.L. Interannual variability in Dinophysis spp. abundance and toxin accumulation in farmed mussels (Perna perna) in a subtropical estuary. Environ. Monit. Assess. 2018. [CrossRef] [PubMed]

81. Trochimczuk-Fo, A.; Schettini, C.A.F. Avaliação da dispersão espacial da pluma do estuário do rio Itajaí-Açu em diferentes períodos de descarga. Braz. J. Aquat. Sci. Technol. 2003, 7, 83-96. [CrossRef]

82. Schettini, C.A.F.; Carvalho, J.L.B.; Truccolo, E.C. Aspectos Hidrodinâmicos da Enseada da Armação de Itapocoroy, SC. Braz. J. Aquat. Sci. Technol. 1999, 3, 99. [CrossRef]

83. Schettini, C.A.F.; Resgalla, C., Jr.; Pereira-Fo, J.; Silva, M.A.C.; Truccolo, E.C.; Rörig, L.R. Variabilidade temporal das características oceanográficas e ecológicas da região de influência fluvial do rio Itajaí-Açu. Braz. J. Aquat. Sci. Technol. 2005, 9, 93-102. [CrossRef]

84. EURLMB EU-Harmonised Standard Operating Procedure for Determination of Lipophilic Marine Biotoxins in Molluscs by LC-MS/MS, Version 5. 2015, pp. 1-31. Available online: www.aesan.msps.es/en/CRLMB/ web/home.shtml (accessed on 7 May 2017).

85. Edler, L.; Elbrächter, M. The Utermöhl method for quantitative phytoplankton analysis. Microsc. Mol. Methods Quant. Phytoplankt. Anal. 2010, 13-20. [CrossRef]

86. Grasshoff, K.; Kremling, K.; Ehrhardt, M. Methods of Seawater Analysis, 3rd ed.; Grasshoff, K., Kremling, K., Ehrhardt, M., Eds.; Wiley-VCH: Weinheim, Germany; New York, NY, USA; Chiester, UK; Brisbane, Australia; Singapore; Toronto, ON, Canada, 1999; Volume 7, ISBN 3-527-25998-8.

87. Zapata, M.; Rodríguez, F.; Garrido, J.L. Separation of chlorophylls and carotenoids from marine phytoplankton: A new HPLC method using a reversed phase C8column and pyridine-containing mobile phases. Mar. Ecol. Prog. Ser. 2000, 195, 29-45. [CrossRef]

88. R Core Team. R: A Language and Environment for Statistical Computing; R Foundation for Statistical Computing: Vienna, Austria, 2017.

89. Dinno, A. Dunn's Test of Multiple Comparisons Using Rank Sums; The Comprehensive R Archive Network: Portland, OR, USA, 2017.

90. Lê, S.; Josse, J.; Husson, F. FactoMineR: An R Package for Multivariate Analysis. J. Stat. Softw. $2008,25$. [CrossRef]

(C) 2018 by the authors. Licensee MDPI, Basel, Switzerland. This article is an open access article distributed under the terms and conditions of the Creative Commons Attribution (CC BY) license (http:/ / creativecommons.org/licenses/by/4.0/). 